\title{
Endemic Birds of the Seychelles
}

\author{
by Malcolm Penny
}

The author of this survey of the endemic birds of the Seychelles Islands, in the Indian Ocean, was a member of the 1964-65 Bristol University Seychelles Expedition financed by the World Wildlife Fund. He describes the status of ten birds unique to the islands, all of which are today in some degree of danger, and suggests measures that must be taken to save them.

WJEN it was first colonised in the early eighteenth century the Seychelles archipelago supported a varied avifauna with some dozen species occurring in most of the larger islands. As the settlers increased in numbers, and, more important, as they cleared large areas of primary forest and introduced alien species, the native birds declined, so that today most of the endemic birds are to be found on only one or two islands. Two species, a white eye Zosterops semiflava, and a green parakeet Palaeornis wardi, are known to have become extinct.

Records of the early days are scarce and incomplete, but in the nineteenth century several workers visited the islands and brought back progressively more complete accounts of the avifauna. The two most important were E. Newton (1867) and Abbott (in Ridgway 1896). From these accounts and others, including the observations (1966) of the Bristol Seychelles Expedition, a fairly complete picture can be built up of the decline of the avifauna of Seychelles over the last hundred years. This paper seeks to trace this decline and to consider the possibility of checking it in each of the endangered endemic species. An account of the general biology of the avifauna of Seychelles by Gaymer and others of the Bristol expedition is in the press.

\section{Seychelles Magpie Robin, Pie Chanteuse Copyschus seychellarum}

The magpie robin is a conspicuous ground-feeding bird about the size of a blackbird, with the tameness and general demeanour of a robin. The adults are black all over with a deep blue sheen, a white wing-bar, and black legs and bill. Juveniles lack the adult sheen, and have the wing-bar mottled with black, and sometimes also chestnut markings on the feathers. Other members of the genus, which is widespread in the East, are much smaller and tend to have more chestnut coloration.

Newton (1867) records the pie 'in reduced numbers' on Praslin, La Digue, and Marianne, and from hearsay also in the south of Mahé. Oustalet (1878) records its collection by Landz from these islands and also from Aride, and notes that it was said to occur then on Mahé and Félicité. Abbott also took specimens from Alphonse, in the southern Amirantes, where the bird had been introduced. Vesey-Fitzgerald (1940), recording the extinction of the pie in the thirties on Marianne and Aride, noted a small surviving population on Frigate. Landz evidently visited Frigate, but surprisingly did not see the bird. Vesey-Fitzgerald considered Alphonse 'the last main stronghold' of the pie, but when we visited the island in 
1965 we could find neither a bird nor anyone who could remember seeing one for at least six years. The small group on Frigate, not more than 20 birds, is now the sole surviving population of this species (Dawson 1965). By synchronised counts with four observers we were able to record only eight individuals in view at one time, and our final estimate was that the island supported not more than fifteen birds, but in $1967 \mathrm{~A}$. Beamish (pers. comm.), using similar counting methods with three observers, recorded fifteen birds at one time, which raises the estimate of the total population, but not above about 20 birds.

The ground-feeding habit of the pie makes it vulnerable to ground predators against which, as they are absent from Seychelles, it has evolved no defence. On other islands rats and cats have probably combined to do the damage, but on Frigate, where rats are absent and carefully excluded, the destruction of the pie is due entirely to feral cats. In 1960 more than eighty cats were killed in a Department of Agriculture drive, but some still remain and are presumably taking a toll of the tiny pie population.

Although the population would seem to have been stable since Crook's 1959 estimate of twenty birds, there can be no doubt that the bird will be extinct in a very short time unless something drastic is done. The extermination of feral cats is notoriously difficult, but given sufficient incentive and application it is not impossible. Of the other possibilities, the removal of the population to another more suitable island is hardly feasible in Seychelles, where nearly all the islands have suffered alike. Cousin, which might serve as a refuge, having no ground predators and some suitable cover, is ruled out because of its nearness to Praslin; there are also some doubts about the effects of competition with Cousin's own unique endemic bird, Nesillas seychellensis. The other possibility is propagation in captivity. The bird is admirably tame, and well suited to life in an aviary (the type specimen came from a cage in Mauritius), but its nest site, high in a coconut palm (Vesey-Fitzgerald) makes successful captive breeding unlikely.

The only hope for the conservation of this important bird, a monotypic species showing both gigantism and melanism, both characteristic of remote island populations, would seem to lie in a renewed and concentrated drive against cats on Frigate; and, of course, the continued exclusion of rats.

Seychelles Black Paradise Flycatcher, Veuve Terpsiphone (Tchitrea) corvina The male veuve is blue-black all over, with a deep blue sheen, pale blue facial skin, and greatly elongated central tail feathers. The female has a black head without the facial skin, chestnut wings and mantle, and white underparts flecked posteriorly. The veuve is a lowland forest species, insectivorous, and exceedingly agile in flight. Specimens were taken in 1865 from Praslin, and in 1877 also from Marianne. Abbott, in 1892, took the species on Marianne and La Digue, but there is no record from other islands. In 1940 the veuve was restricted to La Digue, having been exterminated from the other islands presumably by clearance of lowland timber. 
In February 1965 we counted fewer than 30 individuals on La Digue, deriving the total from the number of occupied nests and a few fledged juveniles and unpaired males. Counting was simplified by the territorial behaviour of breeding pairs, which made nests easy to find, and by the birds' habit of nesting only on the coastal 'plateau'. Out of the breeding season, as observed in October 1964, the pairs merge into small flocks, which range widely over the plateau and some distance up the hillsides (Penny 1965c). Counting at this time would be most inaccurate.

The population is threatened by human interference and by the clearing of lowland timber for coconut or vanilla plantations. The veuve chooses its nest site for safety from attack by tree-climbing predators such as geckos, and for ease of access by the bird. Thus a nest tends to be built at the end of a thin down-hanging branch at the edge of a tree, usually over a clearing such as a path or house yard.

La Digue is a very densely populated island, with the houses scattered in clearings in the woodland. Paths are numerous through the woods, and much used. Nest-building for the veuve is thus a protracted task, for since disturbance more often leads to desertion as the nest is more nearly completed, several attempts may have to be made before a nest is actually suitable for laying, as can be seen from the number of partly built new nests. Once nesting and laying are complete, the site of the nest still lays it open to disturbance by man, either accidentally by some activity such as coconut cutting, or deliberately by the mischief of children and other irresponsible persons. From the number of locals who offered to catch veuves for us for money, we inferred that some earlier collector might even have given the bird a cash value by paying for specimens.

As land values rise, La Digue will have to be more economically exploited, and thus further clearance and drainage of the damp plateau woodland is inevitable. This will tend to reduce the veuve population. The present rate of new clearing on La Digue might dismay both conservationist and economist, though for opposite reasons. Here is one of the central problems of conservation in Seychelles. Where edible or commercially valuable game is involved, the situation is simplified by the possibility of cropping; but with a small population of a small bird, care and even cunning must be exerted to convince the non-zoologist of its value before economic demands lead to its extermination.

It is just possible that a smaller population of veuves than now exists might survive if sufficient cover were left. The size of such a population is open to debate and decision by later workers, but methods of public education, however bizarre, should aim to ensure that the risk to such a reduced population from human interference be minimised. In an attempt to start educating the local people to appreciation of the veuve, the Expedition presented wall-charts to the local school demonstrating in simple English the uniqueness of the bird, comparing it to the other birds which are to be seen on La Digue. Propaganda was also disseminated through the parish priest and the scout troop. We hear now (A. Beamish. pers. comm.) that a popular song extolling the veuve has been written and accepted with acclaim. 
Black Parrot Coracopsis nigra barklyi

A small grey vasa parrot, scruffy in appearance and secretive in behaviour (except vocally), the black parrot is one of the best-known birds of Seychelles because it appears on the 5 cent postage stamp. Its Creole name, 'cateau noir', is almost never used; the stamp bears only the English name.

Past records are from Praslin and Marianne (Oustalet 1877). Its piercing voice makes the parrot a bird unlikely to have been overlooked, so that it is probable that in historical times (for Seychelles, since the early eighteenth century) it did not occur on other islands, though it may have been on Curieuse, an island off Praslin which once bore similar vegetation, but was usually ignored by the early visitors.

It seems likely that the numbers of the parrot were higher within living memory than they are now, for the bird is still regarded as a pest of fruit trees, and we heard tales of mass raids on mango trees in the past. Now it is a regular visitor only to parts of Praslin within a mile or so of the Vallée de Mai Nature Reserve, where the population seems to be concentrated.

The Expedition had great difficulty in estimating the present population, and resorted at last to the method of synchronised observation from dusk to dawn, an exercise described in Penny 1965b. We accounted for 17 birds in view at one time, and came to the conclusion that although the Vallée de Mai is the most likely place to see parrots, they do not roost there exclusively. Our final estimate of the population, after several visits, was small, between $\mathbf{3 0}$ and $\mathbf{5 0}$ individuals, but this is offered as no more than a careful guess at the right order of magnitude.

It has been suggested that the reason for the concentration of parrots in the valley is the fine stand there of Laodicea maldivicum, the unique coco de mer or double coconut of Seychelles. It seems to us, however, that this connection may not be direct, but more the result of the preservation of the valley as a nature reserve, where the parrots are safer from disturbance than elsewhere in the island. However, what is known of the birds' nesting requirements (Lalanne 1960) indicates that established endemic palm forests provide the best nesting sites, which are usually at the top of dead but standing palm trunks. Parts of the valley, and one nearby hillside outside its boundaries, provide the only surviving stands of this kind on Praslin.

Now that protection by law and the reduction of the parrot's numbers have combined to stop the slaughter of the bird by islanders, the limiting factors on the population are probably a shortage of nesting sites and of food. Destruction of the endemic palms must have caused the bird's extinction from Marianne. To provide sufficient nesting sites it is essential that the small area of remaining palm forest be preserved as well as the Vallée de Mai. We found one other such area, described by VeseyFitzgerald in 1940; it turned out to be the site of a new Government hardwood plantation. We made strong representations that the same fate should not overtake the last remaining area outside the reserve.

In order to augment the nest-sites available in the Vallée de Mai we erected experimental 'nesting boxes' in the form of $4 \mathrm{ft}$. lengths of fallen Laodicea trunks wired to the trunks of standing trees, about $20 \mathrm{ft}$. from 
the ground. We have not yet heard whether this has proved successful, but the Forestry Department is to keep them under observation.

To restrict the parrots still more to the valley, and thus to reduce their foraging visits to other parts of the island where they might be endangered, we have suggested that fruit trees should be planted round the edge of the Vallée de Mai. The policy of the Department of Agriculture is to preserve the valley itself for endemic plants, exotics being gradually rooted out, but since most of the surrounding land is owned by the Crown, fruit trees could be planted as the other plantations are overhauled.

It is difficult to suggest more concrete methods for the conservation of a bird whose biology is so imperfectly known, but the danger of its accidental extermination should constantly be borne in mind.

Seychelles Turtle Dove, Tourterelle Rouge Streptopelia picturata rostrata This endemic subspecies is distinguished from the nominate form, an introduction from Madagascar, by its vinous red head and mantle, grey tail, and darker buff underparts. S.p. picturata was introduced in the 1850 s, judging from Newton's account. It has a grey head, a mantle tending to chestnut, a brown tail, and pale creamy underparts. These field characters are supported by measurements of the wings of museum specimens and some in the field, the endemic form having a wing on average about $20 \mathrm{~mm}$. shorter than that of the introduction. These characters, especially the darker colour and shorter wing, are typical of island races. (Benson 1967).

The descriptions of these birds are given at some length to illustrate the problem of the conservation, if such it can be called, of the island form. To separate the two subspecies in the field is made almost impossible by the degree of interbreeding between them. Vesey-Fitzgerald stated that 'it is not evident that more than one race exists at the present time' (1940), but this is overstating the position. Most birds seen are intermediate picturata $x$ rostrata, with a tendency more closely to resemble the introduced form at least in field characters. Measurements of a few netted specimens showed them to be intermediate in size. On Cousin Island, however, though some interbreeding has occurred, the birds tend much more towards the endemic form. Why this should be so is difficult to see, for the intervening two miles of sea can hardly constitute much of a geographical barrier to a turtle dove. It seems possible, though we did not investigate it, that the population density in that part of Praslin nearest to Cousin is not high enough to encourage much expansion to the smaller island. However this may be, the conservation of the endemic subspecies is more likely to be effected by breeding it back in an aviary than by more orthodox methods. Cousin, when a research station is set up there, would offer excellent facilities for this work, which might at least preserve an example to show the tendency of evolution in a group of small remote islands.

White-bellied White-eye, Oiseau Lunette Zosterops modesta Seychelles Bare-legged Scops Owl, Scieur Otus insularis

These two species are taken together as examples of very rare birds about which little is known, both thought at one time to be extinct, and both 
recently rediscovered in more or less remote parts of the mountains of central Mahé. A congeneric white-eye, $Z$. semiflava, is extinct in Seychelles (Gaymer 1965) though in the nineteenth century it was reported from Marianne, Praslin, and Silhouette and thought to occur also on Mahé and $\mathrm{La}$ Digue. $Z$. modesta was reported by these workers from Mahé only, and was thought to have become extinct in the twentieth century, but it was rediscovered in the fifties at La Misère, a mountain pass in north Mahé, (Lalanne 1960), where we saw a group of about 20.

The owl, although described in 1880 , receives no mention by any later writer until Lalanne (1960). It seems always to have been restricted to the remote high forests of Mahé, and at least some authorities thought it was extinct when, in 1964, the Brooke Bond tea company included it in a series of cards featuring extinct birds of the world. After much searching of high forest areas where it has been heard regularly by foresters and charcoal burners, who did not know that it was supposed to be extinct, we saw three individuals at Castor, in the mountains of central Mahé.

The diets of these two birds can only be guessed at, their nests have never been described, and most visitors to Seychelles do not see them, but they survive in the few small patches of mountain forest left on Mahé after the fires of the past and the clearing which is still going on. Their continued survival depends on the preservation of at least some of the high forest, either by law or because it proves too inaccessible for development. It should be added here that the entomology of the heights of Seychelles has not been worked out, and that several tree frogs and a chameleon endemic to the islands also depend on the high forest. Both these considerations add weight to the arguments for preservation, which in our view should not be left to chance.

\section{Seychelles Blue Pigeon, Pigeon Hollandais Alectroenas pulcherrima Seychelles Kestrel, Katiti Falco area}

The endemic pigeon, a handsome blue and white bird with a red wattle, and the small endemic kestrel, found in declining numbers on certain of the larger islands, are taken together since they present rather similar problems to the conservationist.

The pigeons have declined rapidly, as a result of shooting and liming for the pot, since the time when Newton described huge flocks at Cascade on Mahé. Even since the last war, they have become much less common, according to a reliable informant who could remember seeing flocks of them on fruit trees on Praslin, a sight not to be seen now, when the largest groups seldom number more than a dozen individuals. We saw pigeons most commonly on Praslin, but still in small numbers, and also on Mahé, Silhouette, and Frigate. (They seem never to have occurred on La Digue, which lacks suitable wooded hillsides.) We were frequently regaled with stories of their excellence as meat.

This would seem to be a clear case for legal conservation, for the surviving pigeons have adapted successfully to the new habitats of the developing Seychelles, and are limited only by human predation. In fact they have been protected by law since 1906, but quite ineffectually on 
the remote and unpatrolled hillsides where they live. Their survival cannot be ensured in this way.

We saw the kestrel on Mahé and Praslin, though not on Silhouette despite a search. We were told that it occurred recently on La Digue (though none of the nineteenth century workers saw it there), but that it had been displaced from its nesting sites by the introduced barn owl. ${ }^{1}$ The local belief is that kestrels kill chickens and in the past they have been killed as pests. The fact that they are too small to take anything much bigger than a day-old chick seems to have escaped public attention. They are easy to catch after they have made a kill, for they have no behavioural defence against ground predators and feed where they kill. Small boys are wont to take feeding birds by hand when they have a chance.

The pigeon is known to be getting scarce in the islands (perhaps from the reports of unsuccessful hunters), but the kestrel is thought to be much more numerous than in fact it is. In almost any area of plateau on Mahé a kestrel may eventually be seen, hovering above the coconut palms, or perched on one of its hunting posts. Sometimes a bird may venture some way up the hillside and hunt there. What is not realised is that all the sightings of kestrels over the plateau behind one bay are probably of the same pair, which can control a very large territory and will exclude rival kestrels from nesting or hunting there.

The conservation of both these species depends upon education to make people realise their rarity and importance. To kill pigeons for meat may be natural, but careful propaganda might well induce people to see them as decorative additions to the natural beauty of Seychelles. With the kestrel, people could be taught both how to protect their chicks in covered runs and to appreciate the thrill of watching a kestrel hunting lizards. Of course the efficiency with which the police enforce the protection laws could be increased, but they are few in number and have other duties; as indicated above, the factor which has caused the decline of these species, and the one which must be altered to ensure their survival, is the attitude of the local people.

\section{Seychelles Fody, Toq Toq Foudia sechellarum. \\ Seychelles Brush Warbler, Petit Merle des Isles Nesillas (Bebrornis) sechellensis.}

The fody and the warbler are included together for two reasons: first, although both have declined in numbers and distribution, they now maintain stable populations where they still occur, and second, both are on Cousin Island, which is being purchased by conservation interests, as described in the last issue of ORYX (December, 1967).

The past distribution of the fody seems to have been restricted to Marianne, where it is now extinct (Crook 1960), and three other small islands, Frigate in the east of Seychelles, and Cousin and Cousine off Praslin (Penny 1965a). All the three last-named still support good popula-

${ }^{1}$ An ill-advised introduction, designed to combat rats, the barn owl has done serious damage to the populations of some of the endemic birds. Since our visit it has been taken off the protected list, and the Department of Agriculture offers a bounty for dead specimens. 
tions, with evidence of divergence between Frigate and the Cousins (Crook loc.cit., and Blackman, unpublished $\mathrm{ms}$ ). The extinction of the species from Marianne was almost certainly due to the complete destruction of the vegetation of that island in the 1870 s to make a coconut plantation. Its survival on the other islands is due to the varied nature of the agriculture there.

The warbler was described by Landz as occurring on Marianne and 'rare on île Cousine'. By this he presumably meant Cousin, where the species persists: if it did occur on Cousine it is extinct there now.

The catastrophic destruction of Marianne must have wiped out the warbler as well as the fody. It is sad to read Newton's report of Marianne, 'every tree seeming to contain one bird or more', knowing its present barrenness of endemic bird life. During our expedition we feared that Cousin would suffer the same fate, but its purchase as a sanctuary should mean that the birds there are now safe.

\section{SUMMARY}

1. The populations of the endemic avifauna of Seychelles have declined in numbers, some very seriously, during the last hundred years. Only those in danger of extinction are discussed here.

2. The magpie robin population is reduced to a score of birds; the population will soon be extinct unless drastic action is taken.

3. The population of the paradise flycatcher is reduced to about 30 birds; conservation must take the form of propaganda, especially since the population is in danger of being reduced still further by the economic development of La Digue.

4. The population of the black parrot is small, probably as a result of the destruction of its habitat. The remaining palm forest on Praslin should be preserved.

5. The endemic turtle dove is probably lost by interbreeding with an introduced form, but on Cousin Island it could possibly be bred back in captivity.

6. The surviving white-eye and the scops owl are very rare, and restricted to small areas of Mahé where mountain forest persists. They are relatively safe unless clearance reaches such inaccessible places.

7. The blue pigeon and the kestrel are getting scarce, through human predation and misinformed destruction respectively; they can only be conserved through careful public education.

8. The endemic fody and the brush warbler, though reduced in numbers, may be presumed to be safe, since Cousin is being bought by conservation interests.

\section{REFERENCES}

ABBOTT (1896) (see Ridgway 1896).

BENSON, C. W., 1967. Atoll Research Bulletin (issue on Aldabra, in press).

BLACKMAN, R. A. A., 1965. Biological control (Effects of barn owl introduction). Animals 8, no. 3: 72-74.

BLACKMAN, R. A. A., Divergence in Foudia populations (MS in preparation). BRISTOL SEYCHELLES EXPEDITION Report on WWF Project No. 118 Submitted 1966. 
CROOK, J. H., 1960. Present status of rare land birds. Seychelles Government Bulletin, January, 1960.

CROOK, J. H., 1961. The fodies of Seychelles. Ibis 103A: 517-548.

DAWSON, P., 1965. Frigate, home of the magpie robin. Animals 7 No. 19: 520522.

GAYMER, R. 1965. The islands' endangered species. Animals 6 No. 19: 544-547 (includes map).

LALANNE, P. L., 1960. Land birds of Seychelles. Seychelles Society Special Publication.

LANDZ, (see Oustalet).

NEWTON, E. 1867. Ibis (2) 3: 335-360 (account of visit).

OUSTALET 1877. Bull. Soc. Philom. Paris (7) 1: 103 (de I'Isle's collection).

OUSTALET 1878. Bull. Soc. Philom. Paris (7) 2: 161-206 (Landz's visit).

PENNY, M., 1965a. Studying the rare birds of Cousin. Animals 7 No. 3: 58-60.

PENNY, M., 1965b. The black parrot of Praslin. Animals 7 No. 7: 184-186.

PENNY, M., 1965c. The Seychelles black paradise flycatcher. Animals 7: No. 11 304-306.

PENNY, M. 1967. A new sanctuary in the Seychelles. Oryx Vol. 9 No. 3.

RIDGWAY, R., 1896. Proc. U.S. Nat. Hist. Mus. 18: 513-546 (Abbott's collection).

VESEY-FITZGERALD, D. F., 1940. Ibis (14) 4: 480-489 (survey of land birds).

\section{Birds of South America}

\section{The Birds of Chile and adjacent regions of Argentina, Bolivia and} Peru, Volume II, by A. W. Johnson. Casilla 327, Santiago, Chile, £7.

The second and final volume of this standard work, published in Spanish in 1946-51 under the title Las Aves de Chile is now issued, two years after the first (reviewed in ORYX, December, 1966). It starts with the gulls and terns and concludes with the finches. Like the first volume, it is not a mere translation of the Spanish text, from which it differs by a great amount of supplementary information on every species so far recorded from Chile and adjacent countries (all areas where habitats are similar to those of the Andean regions of Chile). Therefore it includes 74 forms not yet recorded from Chilean territory, but confined to the same habitat in Argentina, Bolivia and Peru.

This excellent book gives all available information on the characteristics of birds, their biology and distribution. The field marks are given, and for the passerines a technical description is also detailed, the differences between allied species being impossible to summarise in a short field key. Nests and eggs of over a hundred species are described for the first time, and English names have been standardised with those of Schauensee and Eisenmann's book on South American birds. The 104 colour plates by J. A. Goodall are of low artistic value but accurate and useful for identification. A series of photographs shows a variety of habitats and nest sites.

The most valuable handbook available on South American birds, covering much of the entire southern part of the continent, this book constitutes a key to a highly specialised avifauna, based on museum work and the author's own field experience. It will instigate Chilean ornithology to rapid further progress (the number of additional notes to Volume I demonstrate the vitality of ornithological researches in that country.) It will also help the conservation of bird life in Chile and make steady progress; the regulations recently issued by the Government are a very encouraging sign.

JEAN DORST 